\title{
Disinfection, sterilization, and antisepsis: An overview
}

\author{
William A. Rutala PhD, MPH, CIC ${ }^{\text {a,* }}$, David J. Weber MD, MPH ${ }^{\mathrm{a}, \mathrm{b}}$ \\ a Division of Infectious Diseases, University of North Carolina School of Medicine, Chapel Hill, NC \\ ${ }^{\mathrm{b}}$ Department of Hospital Epidemiology, University of North Carolina Hospitals, Chapel Hill, NC
}

Key Words:

Disinfection

Sterilization

Antisepsis

\begin{abstract}
All invasive procedures involve contact by a medical device or surgical instrument with a patient's sterile tissue or mucous membranes. The level of disinfection or sterilization is dependent on the intended use of the object. Critical (items that contact sterile tissue, such as surgical instruments), semicritical (items that contact mucous membranes, such as endoscopes), and noncritical (devices that contact only intact skin, such as stethoscopes) items require sterilization, high-level disinfection, and low-level disinfection, respectively. Cleaning must always precede high-level disinfection and sterilization.

Antiseptics are essential to infection prevention as part of a hand hygiene program, as well as other uses, such as surgical hand antisepsis and preoperative skin preparation.
\end{abstract}

Each year in the United States, there are approximately $53,000,000$ outpatient surgical procedures and 46,000,000 inpatient surgical procedures. ${ }^{1}$ For example, there are at least 18 million gastrointestinal endoscopies per year. ${ }^{2}$ Each of these procedures involves contact by a medical device or surgical instrument with a patient's sterile tissue or mucous membranes. A major risk of all such procedures is the introduction of infection. Failure to properly disinfect or sterilize medical devices and surgical instruments may lead to transmission via these devices (eg, endoscopes contaminated with carbapenem-resistant Enterobacteriaceae). ${ }^{3}$

Achieving disinfection and sterilization by disinfectants and sterilization practices is essential for ensuring that medical and surgical instruments do not transmit infectious pathogens to patients. Health care policies must identify whether cleaning, disinfection, or sterilization is indicated based primarily on the items' intended use. This article will capsulize and update other articles on this subject as well as provide updated information regarding newer sterilization, disinfection, and antisepsis technologies and practices. ${ }^{4-7}$

\section{A RATIONAL APPROACH TO DISINFECTION AND STERILIZATION}

Fifty years ago, Spaulding ${ }^{8}$ devised a rational approach to disinfection and sterilization of patient care items and equipment. This

\footnotetext{
* Address correspondence to William A. Rutala, PhD, MPH, CIC, Division of Infectious Diseases, University of North Carolina School of Medicine, 130 Mason Farm Rd, Bioinformatics Bldg, CB \#7030, Chapel Hill, NC 27514-7030.

E-mail address: brutala@med.unc.edu (W.A. Rutala).

Conflicts of interest: Dr. Rutala is a consultant to PDI and ASP. Dr. Weber is a consultant for PDI and Germitec.
}

classification scheme is so clear and logical that it has been retained, refined, and successfully used by infection control professionals and others when planning methods for disinfection and sterilization. ${ }^{4-10}$ Spaulding believed that the nature of disinfection could be understood more readily if instruments and items for patient care were divided into 3 categories based on the degree of risk of infection involved in the use of the items. The 3 categories he described were critical (enters sterile tissue and must be sterile), semicritical (contacts mucous membranes or nonintact skin and requires high-level disinfection), and noncritical (comes in contact with intact skin and requires low-level disinfection). These categories and the methods to achieve sterilization, high-level disinfection, and low-level disinfection are summarized in Table 1. Although the scheme remains valid, there are some examples of disinfection studies with prions, viruses, mycobacteria, and protozoa that challenge the current definitions and expectations of high- and low-level disinfection. ${ }^{11}$

\section{Critical items}

Critical items are so-called because of the high risk of infection if such an item is contaminated with any microorganism, including bacterial spores. Thus, it is critical that objects that enter sterile tissue or the vascular system be sterile because any microbial contamination could result in disease transmission. This category includes surgical instruments, cardiac and urinary catheters, and implants. The items in this category should be purchased as sterile or sterilized by steam sterilization, if possible. If heat-sensitive, the object may be treated with ethylene oxide, hydrogen peroxide gas plasma, vaporized hydrogen peroxide, hydrogen peroxide vapor and ozone, or liquid chemical 
Table 1

Methods for disinfection and sterilization of patient care items and environmental surfaces*

\begin{tabular}{|c|c|c|c|c|}
\hline Process & $\begin{array}{l}\text { Level of microbial } \\
\text { inactivation }\end{array}$ & Method & Examples (with processing times) & Health care application (examples) \\
\hline Sterilization $^{\dagger}$ & $\begin{array}{l}\text { Destroys all } \\
\text { microorganisms, } \\
\text { including } \\
\text { bacterial spores }\end{array}$ & $\begin{array}{l}\text { High temperature } \\
\text { Low temperature } \\
\text { Liquid immersion }\end{array}$ & $\begin{array}{l}\text { Steam ( } \sim 40 \text { min), dry heat ( } 1-6 \mathrm{~h} \text {, depending on } \\
\text { temperature) } \\
\text { Ethylene oxide gas ( } \sim 15 \mathrm{~h}) \text {, HP gas plasma } \\
(28-38 \text { min, NX), HP and ozone ( } 46-70 \mathrm{~min} \text {, } \\
\text { VP4), HP vapor }(28-55 \text { min, V-PRO maX) } \\
\text { Chemical sterilants : }>2 \% \text { glut }(\sim 10 \mathrm{~h} \text { at } \\
\left.20^{\circ} \mathrm{C}-25^{\circ} \mathrm{C}\right), 1.12 \% \text { glut with } 1.93 \% \text { phenol } \\
\left(12 \mathrm{~h} \text { at } 25^{\circ} \mathrm{C}\right), 7.35 \% \mathrm{HP} \text { with } 0.23 \% \mathrm{PA}(3 \mathrm{~h} \\
\left.\text { at } 20^{\circ} \mathrm{C}\right), 7.5 \% \mathrm{HP}\left(6 \mathrm{~h} \text { at } 20^{\circ} \mathrm{C}\right), 1.0 \% \mathrm{HP} \\
\text { with } 0.08 \% \mathrm{PA}\left(8 \mathrm{~h} \text { at } 20^{\circ} \mathrm{C}\right), \sim 0.2 \% \mathrm{PA} \\
\left(12 \mathrm{~min} \text { at } 50^{\circ} \mathrm{C}-56^{\circ} \mathrm{C}\right)\end{array}$ & $\begin{array}{l}\text { Heat-tolerant critical (surgical instru- } \\
\text { ments) and semicritical patient care } \\
\text { items } \\
\text { Heat-sensitive critical and semicritical } \\
\text { patient care items } \\
\text { Heat-sensitive critical and semicritical } \\
\text { patient care items that can be } \\
\text { immersed }\end{array}$ \\
\hline $\begin{array}{l}\text { High-level } \\
\text { disinfection }\end{array}$ & $\begin{array}{l}\text { Destroys all micro- } \\
\text { organisms except } \\
\text { some bacterial } \\
\text { spores }\end{array}$ & $\begin{array}{l}\text { Heat-automated } \\
\text { Liquid immersion }\end{array}$ & $\begin{array}{l}\text { Pasteurization }\left(65^{\circ} \mathrm{C}-77^{\circ} \mathrm{C}, 30 \text { min }\right) \\
\text { Chemical sterilants/HLDs }:>2 \% \text { glut }(20-90 \text { min } \\
\left.\text { at } 20^{\circ} \mathrm{C}-25^{\circ} \mathrm{C}\right),>2 \% \text { glut }\left(5 \text { min at } 35^{\circ} \mathrm{C}\right), 0.55 \% \\
\text { OPA }\left(12 \text { min at } 20^{\circ} \mathrm{C}\right), 1.12 \% \text { glut with } 1.93 \% \\
\text { phenol }\left(20 \text { min at } 25^{\circ} \mathrm{C}\right), 7.35 \% \mathrm{HP} \text { with } 0.23 \% \\
\mathrm{PA}\left(15 \text { min at } 20^{\circ} \mathrm{C}\right), 7.5 \% \mathrm{HP}\left(30 \text { min at } 20^{\circ} \mathrm{C}\right) \text {, } \\
1.0 \% \mathrm{HP} \text { with } 0.08 \% \mathrm{PA}\left(25 \text { min at } 20^{\circ} \mathrm{C}\right), 650- \\
675 \text { free chlorine }\left(10 \text { min at } 25^{\circ} \mathrm{C}\right), 2.0 \% \mathrm{HP} \\
\left(8 \text { min at } 20^{\circ} \mathrm{C}\right), 3.4 \% \text { glut with } 20.1 \% \text { isopropa- } \\
\text { nol }\left(5 \text { min at } 25^{\circ} \mathrm{C}\right)\end{array}$ & $\begin{array}{l}\text { Heat-sensitive semicritical items (eg, } \\
\text { respiratory therapy equipment) } \\
\text { Heat-sensitive semicritical items (eg, } \\
\text { GI endoscopes, bronchoscopes, endo- } \\
\text { cavitary probes) }\end{array}$ \\
\hline $\begin{array}{l}\text { Low-level } \\
\text { disinfection }\end{array}$ & $\begin{array}{l}\text { Destroys vegetative } \\
\text { bacteria and some } \\
\text { fungi and viruses, } \\
\text { but not mycobac- } \\
\text { teria or spores }\end{array}$ & Liquid contact & $\begin{array}{l}\text { EPA-registered hospital disinfectant with no } \\
\text { tuberculocidal claim (eg, chlorine-based prod- } \\
\text { ucts, phenolics, improved HP, HP plus PA, } \\
\text { quats, quats plus alcohol, or } 70 \%-90 \% \text { alcohol. } \\
\text { Exposure time } \geq 1 \mathrm{~min} \text { ) }\end{array}$ & $\begin{array}{l}\text { Noncritical patient care items (eg, blood } \\
\text { pressure cuffs) or surfaces (eg, bedside } \\
\text { tables) with no visible blood }\end{array}$ \\
\hline
\end{tabular}

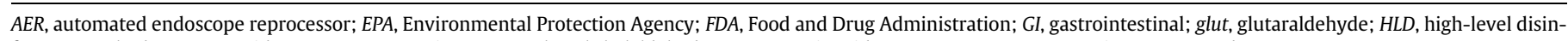
fectant; $H P$, hydrogen peroxide; $N X$, next generation; $O P A$, ortho-phthalaldehyde; $P A$, peracetic acid; quats, quaternary ammonium compounds.

*Modified from Rutala and Weber ${ }^{4-10,46-48}$ and Kohn et al. ${ }^{49}$

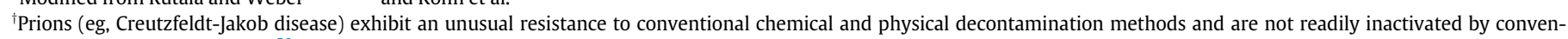
tional sterilization procedures. ${ }^{50}$

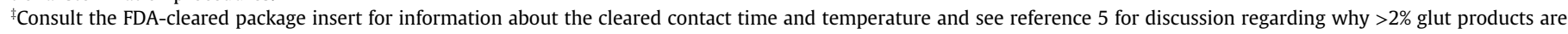

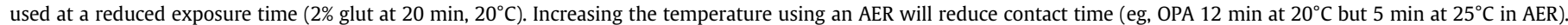

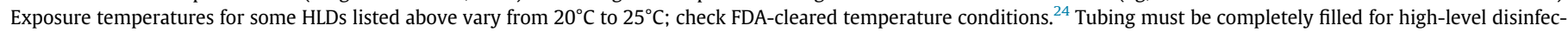

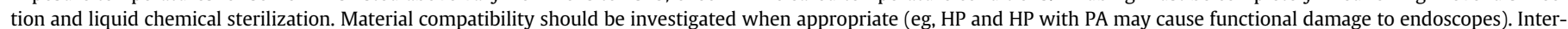

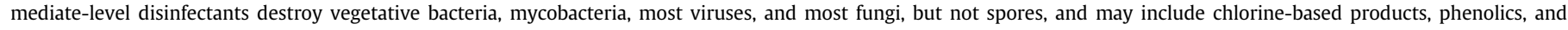

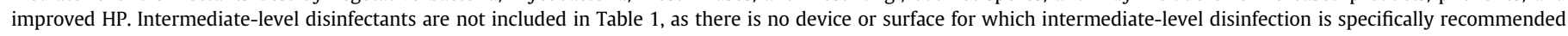
over low-level disinfection.

sterilants, if other methods are unsuitable. Tables 1-3 list sterilization processes, high-level disinfectants, and liquid chemical sterilants and the advantages and disadvantages of each. With the exception of $0.2 \%$ peracetic acid $\left(12\right.$ minutes at $\left.50^{\circ} \mathrm{C}-56^{\circ} \mathrm{C}\right)$, the indicated exposure times for liquid chemical sterilants range from 3 to 12 hours. Liquid chemical sterilants can be relied on to produce sterility only if cleaning, which eliminates organic and inorganic material, precedes treatment and if proper guidelines as to concentration, contact time, temperature, and $\mathrm{pH}$ are met. Another limitation to sterilization of devices with liquid chemical sterilants is that the devices cannot be wrapped during processing in a liquid chemical sterilant; thus, it is impossible to maintain sterility following processing and during storage. Furthermore, devices may require rinsing following exposure to the liquid chemical sterilant with water that, in general, is not sterile. Therefore, because of the inherent limitations of using liquid chemical sterilants in a nonautomated (or automated) reprocessor, their use should be restricted to reprocessing critical devices that are heat-sensitive and incompatible with other sterilization methods.

Sterilization technologies can be relied on to produce sterility only if cleaning-to eliminate organic and inorganic material as well as microbial load-precedes treatment. ${ }^{12-14}$ Other issues sterile reprocessing and operating room professionals must deal with when reprocessing instruments include weight limits for instrument trays, wet packs, packaging, loaned instruments, cleaning monitoring, and water quality..$^{14,15}$

In May 2015, the Food and Drug Administration (FDA) convened a panel to discuss recent reports and epidemiologic investigations of the transmission of infections associated with the use of duodenoscopes in endoscopic retrograde cholangiopancreatography procedures. ${ }^{16}$ After presentations from industry, professional societies, and invited speakers, the panel made several recommendations, to include reclassifying duodenoscopes based on the Spaulding classification from semicritical to critical to support the shift from high-level disinfection to sterilization. This could be accomplished by shifting from high-level disinfection for duodenoscopes to sterilization and modifying the Spaulding definition of critical items from "objects which enter sterile tissue or the vascular system or through which blood flows should be sterile" to "objects which directly or indirectly (ie, via a mucous membrane such as duodenoscope) enter normally sterile tissue of the vascular system or through which blood flows should be sterile." ${ }^{\text {,17-19 }}$ It is noteworthy that in the Spaulding scheme, which identifies how an object should be disinfected or sterilized, he stated that mucous membranes should be intact and that sterilization of semicritical items is desirable. ${ }^{8}$ Implementation of this recommendation requires sterilization technology that achieves a sterility assurance level of $10^{-6}$ of complex medical instruments such as duodenoscopes. Ideally, this shift would eventually involve not only endoscopes that indirectly enter normally sterile tissue (eg, duodenoscopes, bronchoscopes) but also other semicritical devices (eg, gastrointestinal endoscopes). ${ }^{17}$

\section{Semicritical items}

Semicritical items are those that come in contact with intact mucous membranes or nonintact skin. Respiratory therapy and 
Table 2

Summary of advantages and disadvantages of chemical agents used as chemical sterilants or HLDs*

\begin{tabular}{|c|c|c|}
\hline Sterilization method & Advantages & Disadvantages \\
\hline $\mathrm{PA} / \mathrm{HP}$ & - No activation required & $\begin{array}{l}\text { - Material compatibility concerns (lead, brass, copper, zinc), } \\
\text { both cosmetic and functional } \\
\text { - Limited clinical experience } \\
\text { - Mucous membrane and respiratory health effects } \\
\text { - Potential for eye and skin damage }\end{array}$ \\
\hline Glut & $\begin{array}{l}\text { - Numerous use studies published } \\
\text { - Relatively inexpensive } \\
\text { - Excellent material compatibility }\end{array}$ & $\begin{array}{l}\text { - Respiratory irritation from glut vapor } \\
\text { - Pungent and irritating odor } \\
\text { - Relatively slow mycobactericidal activity (unless other dis- } \\
\text { infectants added, eg, phenolics, alcohol) } \\
\text { - Coagulates blood and fixes tissue to surfaces } \\
\text { - Allergic contact dermatitis } \\
\text { - ACGIH recommends limiting employee exposure to ceiling } \\
\text { concentration of } 0.05 \text { ppm }\end{array}$ \\
\hline HP (standard) & $\begin{array}{l}\text { - No activation required } \\
\text { - May enhance removal of organic matter and organisms } \\
\text { - No disposal issues } \\
\text { - No odor or irritation issues } \\
\text { - Inactivates Cryptosporidium at } 6 \%-7.5 \% \\
\text { - Use studies published }\end{array}$ & $\begin{array}{l}\text { - Material compatibility concerns (brass, zinc, copper, and } \\
\text { nickel/silver plating), both cosmetic and functional } \\
\text { - Serious eye damage with contact }\end{array}$ \\
\hline $\mathrm{OPA}$ & $\begin{array}{l}\text { - Fast-acting HLD } \\
\text { - No activation required } \\
\text { - Odor not significant } \\
\text { - Excellent materials compatibility claimed } \\
\text { - Does not coagulate blood or fix tissues to surfaces (claimed) } \\
\text { - Relatively rapid mycobactericidal activity }\end{array}$ & $\begin{array}{l}\text { - Stains protein gray (eg, skin, mucous membranes, clothing, } \\
\text { environmental surfaces) } \\
\text { - More expensive than glut } \\
\text { - Eye irritation with contact } \\
\text { - Slow sporicidal activity } \\
\text { - Anaphylactic reactions to OPA in bladder cancer patients } \\
\text { with repeated exposure to OPA through cystoscopy }\end{array}$ \\
\hline PA & $\begin{array}{l}\text { - Standardized cycle (eg, liquid chemical sterilant processing system using } \\
\text { PA, rinsed with extensively treated potable water) } \\
\text { - Low-temperature }\left(50^{\circ} \mathrm{C}-55^{\circ} \mathrm{C} \text { ) liquid immersion sterilization }\right. \\
\left.\text { - Environmentally friendly by-products (acetic acid, } \mathrm{O}_{2}, \mathrm{H}_{2} \mathrm{O}\right) \\
\text { - Fully automated } \\
\text { - Single-use system eliminates need for concentration testing } \\
\text { - May enhance removal of organic material and endotoxin } \\
\text { - No adverse health effects to operators under normal operating condi- } \\
\text { tions } \\
\text { - Compatible with many materials and instruments } \\
\text { - Does not coagulate blood or fix tissues to surfaces } \\
\text { - Sterilant flows through scope, facilitating salt, protein, and microbe } \\
\text { removal } \\
\text { - Rapidly sporicidal } \\
\text { - Provides procedure standardization (constant dilution, perfusion of } \\
\text { channel, temperature, exposure) }\end{array}$ & $\begin{array}{l}\text { - Potential material incompatibility (eg, aluminum anodized } \\
\text { coating becomes dull) } \\
\text { - Used for immersible instruments only } \\
\text { - Biological indicator may not be suitable for routine } \\
\text { monitoring } \\
\text { - One scope or a small number of instruments can be } \\
\text { processed in a cycle } \\
\text { - More expensive (endoscope repairs, operating costs, } \\
\text { purchase costs) than high-level disinfection } \\
\text { - Serious eye and skin damage (concentrated solution) with } \\
\text { contact } \\
\text { - Point-of-use system, no sterile storage } \\
\text { - AER using 0.2\% PA not FDA cleared as sterilization process } \\
\text { but as HLD }\end{array}$ \\
\hline Improved HP (2.0\%), HLD & $\begin{array}{l}\text { - No activation required } \\
\text { - No odor } \\
\text { - Nonstaining } \\
\text { - No special venting requirements } \\
\text { - Manual or automated applications } \\
\text { - } 12 \text {-month shelf life, } 14 \text {-day reuse } \\
\text { - } 8 \text { min at } 20^{\circ} \mathrm{C} \text { HLD claimed }\end{array}$ & $\begin{array}{l}\text { - Material compatibility concerns because of limited clinical } \\
\text { experience } \\
\text { - Organic material resistance concerns because of limited data }\end{array}$ \\
\hline
\end{tabular}

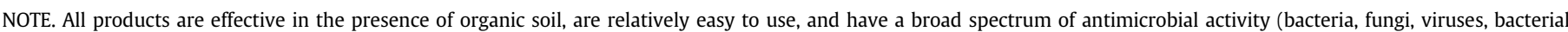

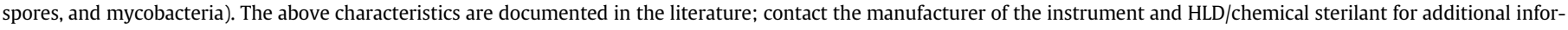
mation. All products listed above are FDA cleared as chemical sterilants, except OPA and 2\% accelerated HP, which are FDA-cleared HLDs.

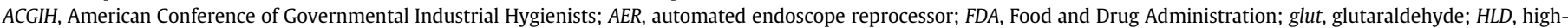
level disinfectant; $H P$, hydrogen peroxide; OPA, ortho-phthalaldehyde; PA, peracetic acid.

*Modified from Rutala and Weber. ${ }^{4-10,46-48}$

anesthesia equipment, some endoscopes, laryngoscope blades and handles, ${ }^{20,21}$ esophageal manometry probes, endocavitary probes, nasopharyngoscopes, prostate biopsy probes, $^{22}$ infrared coagulation devices, ${ }^{23}$ anorectal manometry catheters, cystoscopes, and diaphragm fitting rings are included in this category. ${ }^{20}$ These medical devices should be free of all microorganisms, although small numbers of bacterial spores may be present. FDA's definition of high-level disinfection is a sterilant used for a shorter contact time to achieve at least a $6 \log _{10}$ kill of an appropriate Mycobacterium species. Cleaning followed by high-level disinfection should eliminate all pathogens capable of causing infection.

Intact mucous membranes, such as those of the lungs or the gastrointestinal tract, generally are resistant to infection by common bacterial spores but susceptible to other organisms, such as bacteria, mycobacteria, and viruses. Semicritical items minimally require high-level disinfection using chemical disinfectants. Glutaraldehyde, hydrogen peroxide, ortho-phthalaldehyde, peracetic acid, hypochlorite (via superoxidized water), and peracetic acid with hydrogen peroxide are cleared by the $\mathrm{FDA}^{24}$ and are dependable high-level disinfectants provided the factors influencing germicidal procedures are met (Tables 1 and 2). The exposure time for most high-level disinfectants varies from 8 to 45 minutes at $20^{\circ} \mathrm{C}$ $25^{\circ} \mathrm{C}$. When a disinfectant is selected for use with certain patient care items, the chemical compatibility after extended use with the items to be disinfected must also be considered. The reprocessing of semicritical items such as endoscopes, laryngoscopes, and 
Table 3

Summary of advantages and disadvantages of commonly used sterilization technologies*

\begin{tabular}{|c|c|c|}
\hline Sterilization method & Advantages & Disadvantages \\
\hline Steam & $\begin{array}{l}\text { - Nontoxic to patient, staff, environment } \\
\text { - Cycle easy to control and monitor } \\
\text { - Rapidly microbicidal } \\
\text { - Least affected by organic/inorganic soils among sterilization pro- } \\
\text { cesses listed } \\
\text { - Rapid cycle time } \\
\text { - Penetrates medical packing, device lumens }\end{array}$ & $\begin{array}{l}\text { - Deleterious to heat-sensitive instruments } \\
\text { - Microsurgical instruments damaged by repeated exposure } \\
\text { - May leave instruments wet, causing them to rust } \\
\text { - Potential for burns }\end{array}$ \\
\hline HP gas plasma & $\begin{array}{l}\text { - Safe for the environment and health care personnel } \\
\text { - Leaves no toxic residuals } \\
\text { - Cycle time } 28-38 \text { min and no aeration necessary } \\
\text { - Used for heat- and moisture-sensitive items since process tem- } \\
\text { perature }<50^{\circ} \mathrm{C} \\
\text { - Simple to operate, install ( } 208-\mathrm{V} \text { outlet), and monitor } \\
\text { - Compatible with most medical devices } \\
\text { - Requires only electrical outlet } \\
\text { - Microbicidal efficacy data }\end{array}$ & $\begin{array}{l}\text { - Cellulose (paper), linens, and liquids cannot be processed } \\
\text { - Endoscope and other medical device restrictions based on lumen internal } \\
\text { diameter and length (eg, single- and dual-channel device with stainless steel } \\
\text { lumen that is } \geq 1.0 \mathrm{~mm} \text { in internal diameter and } \leq 150 \mathrm{~mm} \text { in length; see } \\
\text { manufacturer's recommendations) } \\
\text { - Requires synthetic packaging (polypropylene wraps, polyolefin pouches) and } \\
\text { special container tray } \\
\text { - HP may be toxic at levels greater than } 1 \mathrm{ppm} \text { TWA } \\
\text { - Organic matter reduces microbicidal activity }\end{array}$ \\
\hline $100 \%$ ETO & $\begin{array}{l}\text { - Penetrates packaging materials, device lumens } \\
\text { - Single-dose cartridge and negative-pressure chamber minimize } \\
\text { the potential for gas leak and ETO exposure } \\
\text { - Simple to operate and monitor } \\
\text { - Compatible with most medical materials }\end{array}$ & $\begin{array}{l}\text { - Requires aeration time to remove ETO residue } \\
\text { - ETO is toxic, a probable carcinogen, and flammable } \\
\text { - ETO emissions regulated by states, but catalytic cell removes } 99.9 \% \text { of ETO } \\
\text { and converts it to } \mathrm{CO}_{2} \text { and } \mathrm{H}_{2} \mathrm{O} \\
\text { - ETO cartridges should be stored in flammable liquid storage cabinet } \\
\text { - Lengthy cycle/aeration time } \\
\text { - Organic matter reduces microbicidal activity }\end{array}$ \\
\hline Vaporized HP & $\begin{array}{l}\text { - Safe for environment and health care personnel } \\
\text { - Leaves no toxic residue, no aeration necessary } \\
\text { - Cycle time } 28-55 \text { min } \\
\text { - Used for heat- and moisture-sensitive items (metal and non- } \\
\text { metal devices) }\end{array}$ & $\begin{array}{l}\text { - Medical device restrictions based on lumen internal diameter and length (eg, } \\
\text { single-channel device with stainless steel lumen that is } \geq 0.7 \mathrm{~mm} \text { in internal } \\
\text { diameter and } \leq 500 \mathrm{~mm} \text { in length; see manufacturer's recommendations) } \\
\text { - Not used for liquid, linens, powders, or any cellulose materials } \\
\text { - Requires synthetic packaging (polypropylene) } \\
\text { - Limited materials compatibility data } \\
\text { - Limited clinical use data } \\
\text { - Limited comparative microbicidal efficacy data } \\
\text { - Organic matter reduces microbicidal activity }\end{array}$ \\
\hline HP and ozone & $\begin{array}{l}\text { - Safe for environment and health care personnel } \\
\text { - Uses dual sterilants, HP and ozone } \\
\text { - No aeration needed because of no toxic by-products } \\
\text { - Compatible with common medical devices } \\
\text { - Cycle time } 46-70 \text { min } \\
\text { - FDA cleared for general instruments and multichannel flexible } \\
\text { endoscopes (see manufacturer's instructions) }\end{array}$ & $\begin{array}{l}\text { - Endoscope and other medical device restrictions based on lumen internal } \\
\text { diameter and length (eg, single- and dual-channel device with stainless steel } \\
\text { lumen that is } \geq 0.7 \mathrm{~mm} \text { in internal diameter and } \leq 500 \mathrm{~mm} \text { in length; see } \\
\text { manufacturer's recommendations) } \\
\text { - Limited clinical use data } \\
\text { - Limited materials compatibility data } \\
\text { - Limited microbicidal efficacy data } \\
\text { - Requires synthetic packaging (polypropylene wraps, polyolefin pouches) and } \\
\text { special container tray } \\
\text { - Organic matter reduces microbicidal activity }\end{array}$ \\
\hline
\end{tabular}

ETO, ethylene oxide; FDA, Food and Drug Administration; HP, hydrogen peroxide; TWA, time-weighted average.

${ }^{*}$ Modified from Rutala and Weber. ${ }^{4-10,46-48}$

nasopharyngoscopes is discussed in detail in another article in this journal. $^{25}$

Since semicritical equipment has been associated with reprocessing errors that result in patient look-back and patient notifications, it is essential that control measures be instituted to prevent patient exposures. ${ }^{26}$ Before new equipment (especially semicritical equipment, as the margin of safety is less than that for sterilization $)^{3}$ is used for patient care on more than one patient, reprocessing procedures for that equipment should be developed. Staff should receive training on the safe use and reprocessing of the equipment and be competency tested. At University of North Carolina Hospitals, to ensure patient-safe instruments, all staff who reprocess semicritical instruments (eg, instruments that contact a mucous membrane, including vaginal probes, endoscopes, prostate probes) are required to attend a 3-hour class on high-level disinfection of these instruments. The class includes the rationale for and importance of highlevel disinfection and a discussion of high-level disinfectants and exposure times, reprocessing steps, monitoring minimum effective concentration, personal protective equipment, and the reprocessing environment (establishing "dirty-to-clean" flow). Infection control rounds or audits should be conducted at least annually in all clinical areas that reprocess critical and semicritical devices to ensure adherence to reprocessing standards and policies. Results of infection control rounds should be provided to unit managers, and deficiencies in reprocessing should be corrected (immediately, if patient safety issue, such as no brushing of channels) and corrective measures documented to infection control within 2 weeks.

Some items that may come in contact with nonintact skin for a brief period of time (eg, hydrotherapy tanks, ultrasound probes on intact skin [includes central line puncture site]) are usually considered noncritical surfaces and are disinfected with low- or intermediate-level disinfectants. ${ }^{5,27,28}$ Since hydrotherapy tanks have been associated with spread of infection, some facilities have chosen to disinfect them with recommended levels of chlorine. ${ }^{5,27}$

\section{Noncritical items}

Noncritical items are those that come in contact with intact skin but not mucous membranes. Intact skin acts as an effective barrier to most microorganisms; therefore, the sterility of items coming in contact with intact skin is "not critical." Examples of noncritical items are bedpans, blood pressure cuffs, crutches, bed rails, bedside tables, patient furniture, toys, ${ }^{29}$ portable equipment (eg, wheelchairs, infusion pumps, pulse oximeters, medication carts), ${ }^{30,31}$ and floors. ${ }^{32,33}$ 
Table 4

Summary of advantages and disadvantages of disinfectants used as low-level disinfectants*

\begin{tabular}{|c|c|c|}
\hline Disinfectant active & Advantages & Disadvantages \\
\hline Alcohol & $\begin{array}{l}\text { - Bactericidal, tuberculocidal, fungicidal, virucidal } \\
\text { - Fast-acting } \\
\text { - Noncorrosive } \\
\text { - Nonstaining } \\
\text { - Used to disinfect small surfaces (eg, rubber stoppers on medica- } \\
\text { tion vials) } \\
\text { - No toxic residue }\end{array}$ & $\begin{array}{l}\text { - Not sporicidal } \\
\text { - Microbicidal activity affected by organic matter } \\
\text { - Slow-acting against nonenveloped viruses (eg, norovirus) } \\
\text { - No detergent or cleaning properties } \\
\text { - Not EPA registered } \\
\text { - Damages some instruments (eg, hardens rubber, } \\
\text { deteriorates glue) } \\
\text { - Flammable (large amounts require special storage) } \\
\text { - Evaporates rapidly, making contact time compliance } \\
\text { difficult } \\
\text { - Not recommended for use on large surfaces } \\
\text { - Outbreaks ascribed to contaminated alcohol }\end{array}$ \\
\hline $\begin{array}{l}\text { Sodium hypochlorite } \\
\text { (chlorine) }\end{array}$ & $\begin{array}{l}\text { - Bactericidal, tuberculocidal, fungicidal, virucidal } \\
\text { - Sporicidal (in high concentrations) } \\
\text { - Fast-acting } \\
\text { - Inexpensive (in dilutable form) } \\
\text { - Not flammable } \\
\text { - Unaffected by water hardness } \\
\text { - Reduces biofilms on surfaces } \\
\text { - Relatively stable (eg, } 50 \% \text { reduction in chlorine concentration in } \\
30 \mathrm{~d}^{52} \\
\text { - Used as the disinfectant in water treatment } \\
\text { - EPA registered }\end{array}$ & $\begin{array}{l}\text { - Reaction hazard with acids and ammonias } \\
\text { - Leaves salt residue } \\
\text { - Corrosive to metals (some ready-to-use products may be } \\
\text { formulated with corrosion inhibitors) } \\
\text { - Unstable active (some ready-to-use products may be } \\
\text { formulated with stabilizers to achieve longer shelf life) } \\
\text { - Microbicidal activity affected by organic matter } \\
\text { - Discolors/stains fabrics } \\
\text { - Potential hazard is production of trihalomethane } \\
\text { - May cause skin and eye irritation } \\
\text { - Odor (some ready-to-use products may be formulated with } \\
\text { odor inhibitors) } \\
\text { - Irritating at high concentrations }\end{array}$ \\
\hline $\begin{array}{l}\text { Improved (or acceler- } \\
\text { ated) HP }\end{array}$ & $\begin{array}{l}\text { - Bactericidal, tuberculocidal, fungicidal, virucidal } \\
\text { - Fast efficacy } \\
\text { - Easy compliance with wet treatment times } \\
\text { - Safe for workers (lowest EPA toxicity category of IV) } \\
\text { - Benign for the environment } \\
\text { - Nonstaining } \\
\text { - EPA registered } \\
\text { - Not flammable }\end{array}$ & $\begin{array}{l}\text { - More expensive than most other disinfecting actives } \\
\text { - Not sporicidal at low concentrations } \\
\text { - Some material compatibility issues }\end{array}$ \\
\hline Iodophors & $\begin{array}{l}\text { - Bactericidal, mycobactericidal, virucidal } \\
\text { - Not flammable } \\
\text { - Used for disinfecting blood culture bottles }\end{array}$ & $\begin{array}{l}\text { - Not sporicidal } \\
\text { - Shown to degrade silicone catheters } \\
\text { - Require prolonged contact to kill fungi } \\
\text { - Stain surfaces } \\
\text { - Used mainly as antiseptics rather than disinfectants }\end{array}$ \\
\hline Phenolics & $\begin{array}{l}\text { - Bactericidal, tuberculocidal, fungicidal, virucidal } \\
\text { - Inexpensive (in dilutable form) } \\
\text { - Nonstaining } \\
\text { - Not flammable } \\
\text { - EPA registered }\end{array}$ & $\begin{array}{l}\text { - Not sporicidal } \\
\text { - Absorbed by porous materials and irritate tissue } \\
\text { - Depigmentation of skin caused by certain phenolics } \\
\text { - Hyperbilirubinemia in infants when phenolics not prepared } \\
\text { as recommended }\end{array}$ \\
\hline $\begin{array}{l}\text { Quats (eg, didecyldime- } \\
\text { thylammonium bro- } \\
\text { mide, dioctyldimethy- } \\
\text { lammonium bromide) }\end{array}$ & $\begin{array}{l}\text { - Bactericidal, fungicidal, virucidal against enveloped viruses } \\
\text { (eg, HIV) } \\
\text { - Good cleaning agents } \\
\text { - EPA registered } \\
\text { - Surface compatible } \\
\text { - Nonstaining } \\
\text { - Persistent antimicrobial activity when undisturbed } \\
\text { - Inexpensive (in dilutable form) }\end{array}$ & $\begin{array}{l}\text { - Not sporicidal } \\
\text { - In general, not tuberculocidal or virucidal against nonenvel- } \\
\text { oped viruses } \\
\text { - High water hardness can make less microbicidal } \\
\text { - A few reports documented asthma as a result of exposure to } \\
\text { benzalkonium chloride } \\
\text { - Microbicidal activity affected by organic matter } \\
\text { - Absorption by cotton may diminish microbicidal activity } \\
\text { - Multiple outbreaks ascribed to contaminated benzalkonium } \\
\text { chloride }\end{array}$ \\
\hline Alcohol and quat & $\begin{array}{l}\text { - Bactericidal, tuberculocidal, fungicidal, virucidal (enveloped } \\
\text { and many nonenveloped viruses, eg, adenovirus, rotavirus, } \\
\text { enterovirus, rhinovirus) } \\
\text { - Fast-acting } \\
\text { - Surface compatible } \\
\text { - Nonstaining } \\
\text { - Persistent antimicrobial activity when undisturbed } \\
\text { - EPA registered }\end{array}$ & $\begin{array}{l}\text { - Not sporicidal } \\
\text { - Evaporate more rapidly than water-based disinfectants }\end{array}$ \\
\hline $\mathrm{PA} / \mathrm{HP}$ & $\begin{array}{l}\text { - Bactericidal, fungicidal, virucidal, sporicidal (eg, } \mathrm{C} \text { difficile) } \\
\text { - Active in the presence of organic material } \\
\text { - Environmentally friendly by-products (acetic acid, } \mathrm{O}_{2}, \mathrm{H}_{2} \mathrm{O} \text { ) } \\
\text { - EPA registered } \\
\text { - Surface compatible }\end{array}$ & $\begin{array}{l}\text { - Lack of stability } \\
\text { - Potential for material incompatibility (eg, brass, copper) } \\
\text { - More expensive than most other disinfecting actives } \\
\text { - Odor may be irritating } \\
\text { - Can cause mucous membrane and respiratory health effects }\end{array}$ \\
\hline
\end{tabular}

NOTE. If low-level disinfectant is prepared on site (not ready to use), document correct concentration at a routine frequency, as the concentration delivered by automated disinfectant dispensers varies.

C difficile, Clostridium difficile; EPA, Environmental Protection Agency; HP, hydrogen peroxide; PA, peracetic acid; quat, quaternary ammonium compound.

*Modified from Rutala and Weber. ${ }^{4-10,46-52}$ 
Table 5

Antimicrobial spectrum and characteristics of hand hygiene antiseptic agents*

\begin{tabular}{|c|c|c|c|c|c|c|c|}
\hline Group & $\begin{array}{l}\text { Gram-positive } \\
\text { bacteria }\end{array}$ & $\begin{array}{l}\text { Gram-negative } \\
\text { bacteria }\end{array}$ & Mycobacteria & Fungi & Viruses & Speed of action & Comments \\
\hline Alcohols & +++ & +++ & +++ & +++ & +++ & Fast & $\begin{array}{l}\text { Optimum concentration } 60 \%- \\
95 \% \text {, no persistent activity }\end{array}$ \\
\hline $\begin{array}{l}\text { Chlorhexidine } \\
\text { (2\%-4\% aqueous) }\end{array}$ & +++ & ++ & + & + & +++ & Intermediate & $\begin{array}{l}\text { Persistent activity, rare allergic } \\
\text { reactions, not compatible with } \\
\text { some anionic and nonionic } \\
\text { detergents, ototoxicity }\end{array}$ \\
\hline Iodine compounds & +++ & +++ & +++ & ++ & +++ & Intermediate & $\begin{array}{l}\text { Cause skin burns, usually too } \\
\text { irritating for hand hygiene }\end{array}$ \\
\hline Iodophors & +++ & +++ & + & ++ & ++ & Intermediate & Less irritating than iodine \\
\hline Phenol derivative (eg, PCMX) & +++ & + & + & + & + & Intermediate & $\begin{array}{l}\text { Not compatible with nonionic } \\
\text { detergents, ecologic concerns }\end{array}$ \\
\hline Triclosan & +++ & ++ & + & - & +++ & Intermediate & \\
\hline $\begin{array}{l}\text { Quats (eg, benzethonium } \\
\text { chloride, cetrimide) }\end{array}$ & + & ++ & - & - & + & Slow & $\begin{array}{l}\text { Not compatible with anionic } \\
\text { detergents }\end{array}$ \\
\hline
\end{tabular}

NOTE. $+++=$ excellent, ++ = good, + = fair, - = no activity or not sufficient activity.

PCMX, para-chloro-meta-xylenol; quats, quaternary ammonium compounds.

*Modified from Boyce JM, Pittet D. Heathcare Infection Control Practices Advisory Committee. ${ }^{45}$

The 5 most commonly touched noncritical items in the patient environment have been quantitatively shown to be bed rails, bed surfaces, supply carts, overbed tables, and intravenous pumps. ${ }^{34}$ In contrast to critical and some semicritical items, most noncritical reusable items may be decontaminated where they are used and do not need to be transported to a central processing area. There is virtually no documented risk of transmitting infectious agents to patients via noncritical items ${ }^{35}$ when they are used as noncritical items and do not contact nonintact skin, mucous membranes, or sterile tissue. However, these items (eg, bedside tables, bed rails) could potentially contribute to secondary transmission by contaminating hands of health care providers or by contacting medical equipment that will subsequently come in contact with patients. ${ }^{36}$ Tables 1 and 4 list several low-level disinfectants that may be used for noncritical items. Table 4 lists the advantages and disadvantages of the low-level disinfectants that are used on noncritical patient care items (eg, blood pressure cuffs) and noncritical environmental surfaces. The exposure time for low-level disinfection of noncritical items is at least 1 minute.

Many Environmental Protection Agency-registered liquid disinfectants have a 10-minute label claim. However, multiple investigators have demonstrated the effectiveness of these disinfectants against vegetative bacteria (eg, Listeria, Escherichia coli, Salmonella, vancomycin-resistant enterococci, methicillin-resistant Staphylococcus aureus), yeasts (eg, Candida), mycobacteria (eg, Mycobacterium tuberculosis), and viruses (eg, poliovirus) at exposure times of 30-60 seconds. ${ }^{5,37-42}$ Thus, it is acceptable from a microbial inactivation perspective to disinfect noncritical medical equipment (eg, blood pressure cuffs) and noncritical surfaces (eg, bedside tables) with an Environmental Protection Agency-registered disinfectant or disinfectant/detergent at the proper use dilution and a contact time of $\geq 1$ minute. ${ }^{5,43,44}$ Since the typical drying time for a liquid disinfectant or disinfectant towelette on a surface is $1-4$ minutes $^{42}$ and microbial inactivation occurs in 30-60 seconds, ${ }^{40,42}$ one application of the disinfectant with a contact time of $\geq 1$ minute on all hand contact or touchable noncritical surfaces is recommended.

\section{ANTISEPSIS}

Antiseptics are used in health care to reduce the level of microorganisms on the skin to a level unlikely to allow transfer from providers to patients (eg, cross-transmission via hands) or be the nidus of infection (eg, skin preparation prior to insertion of an intravascular device). Table 5 summarizes the antimicrobial spectrum of the antiseptics most commonly used in health care. ${ }^{45}$ Bacterial spores are not listed, as they are not susceptible to available antiseptics and can only be removed mechanically by hand hygiene with soap and water or scrubbing. The most commonly used antiseptics in health care are chlorhexidine (CHG) (alone or in combination with alcohol), alcohol (alone or in combination with $\mathrm{CHG}$ or iodophor), and iodophor (alone or in combination with alcohol). Antiseptics are used for microbial reduction on skin in the following ways: hand hygiene, preoperative showers, preoperative skin preparation, skin preparation prior to insertion of catheters, and routine daily bathing of patients. Regarding this issue, Boyce reviewed several important topics associated with the use of antiseptics to include: current issues in hand hygiene; daily CHG treatment in the intensive care unit; prevention of infection during intravascular access, and best products for skin antisepsis for preoperative bathing, surgical site preparation, and surgical hand scrubs. Antiseptics ( $10 \%$ povidoneiodine) have also been used to decontaminate bone, with minimum sacrifice of cell viability, after dropping a bone graft on the operating room floor. ${ }^{53,54}$

\section{CONCLUSIONS}

When properly used, disinfection and sterilization can ensure the safe use of invasive and noninvasive medical devices. Cleaning should always precede high-level disinfection and sterilization. Strict adherence to current disinfection and sterilization guidelines is essential to prevent patient infections and exposures to infectious agents.

\section{References}

1. Fields R. Outpatient surgeries outnumber inpatient surgeries at 53M procedures a year. Available from: https://www.beckersasc.com/news-analysis/outpatient-surgeries-outnumber-inpatient-surgeries-at-53m-procedures-a-year.html. Accessed January 2019

2. Peery AF, Dellon ES, Lund JC, Crockett SD, McGowan CE, Bulsiewicz WJ, et al. Burden of gastrointestinal disease in the United States: 2012 update. Gastroenterology 2012;143:1179-87.

3. Rutala WA, Weber DJ. Outbreaks of carbapenem-resistant Enterobacteriaceae infections associated with duodenoscopes: what can we do to prevent infections? Am J Infect Control 2016;44(Suppl):47-51.

4. Rutala WA, Weber DJ. Disinfection and sterilization: an overview. Am J Infect Control 2013;41(Suppl):2-5

5. Rutala WA, Weber DJ; Healthcare Infection Control Practices Advisory Committee. Guideline for disinfection and sterilization in healthcare facilities, 2008 Centers for Disease Control and Prevention. Available from: https://www.cdc.gov/infectioncontrol/pdf/guidelines/disinfection-guidelines.pdf. Accessed January 2019.

6. Rutala WA, Weber DJ. Disinfection, sterilization, and antisepsis: an overview. Am J Infect Control 2016;44(Suppl):1-6. 
7. Rutala WA, Weber DJ. Disinfection, sterilization, and control of hospital waste. In: Bennett JE, Dolan R, Blaser MJ, editors. Principles and practice of infectious diseases. Philadelphia (PA): Elsevier. In press.

8. Spaulding EH. Chemical disinfection of medical and surgical materials. In: Lawrence C, Block SS, eds. Disinfection, sterilization, and preservation. Philadelphia (PA): Lea \& Febiger; 1968:517-31.

9. Simmons BP. CDC guidelines for the prevention and control of nosocomial infections. Guideline for hospital environmental control. Am J Infect Contro 1983;11:97-120.

10. Rutala WA. APIC guideline for selection and use of disinfectants. 1994, 1995, and 1996 APIC Guidelines Committee. Association for Professionals in Infection Control and Epidemiology, Inc. Am J Infect Control 1996;24:313-42.

11. McDonnell G, Burke P. Disinfection: is it time to reconsider Spaulding? J Hosp Infect 2011;78:163-70

12. Alfa MJ, DeGagne P, Olson N, Puchalski T. Comparison of ion plasma, vaporized hydrogen peroxide, and $100 \%$ ethylene oxide sterilizers to the 12/88 ethylene oxide gas sterilizer. Infect Control Hosp Epidemiol 1996;17:92-100.

13. Rutala WA, Gergen MF, Weber DJ. Efficacy of a washer-disinfector in eliminating healthcare-associated pathogens from surgical instruments. Infect Control Hosp Epidemiol 2014;35:883-5.

14. Alfa MJ. Monitoring and improving the effectiveness of cleaning medical and surgical devices. Am J Infect Control 2013;41(Suppl):56-9.

15. Seavey R. High-level disinfection, sterilization, and antisepsis: current issues in reprocessing medical and surgical instruments. Am J Infect Control 2013;41 (Suppl):111-7.

16. Food and Drug Administration. Infections associated with reprocessed duodenoscopes. Available from: https://www.fda.gov/medicaldevices/productsandmedicalprocedures/reprocessingofreusablemedicaldevices/ucm454630.htm\#meeting. Accessed January 2019.

17. Rutala WA, Kanamori H, Gergen MF, Sickbert-Bennett EE, Weber DJ. What's new in reprocessing endoscopes: are we going to ensure "the needs of the patient come first" by shifting from disinfection to sterilization? Am J Infect Control 2019;47 (Suppl):A62-6.

18. Rutala WA, Weber DJ. ERCP scopes: what can we do to prevent infections? Infect Control Hosp Epidemiol 2015;36:643-8.

19. Rutala WA, Weber DJ. Gastrointestinal endoscopes: a need to shift from disinfection to sterilization? JAMA 2014;312:1405-6.

20. Rutala WA, Weber DJ. Reprocessing semicritical items: current issues and new technologies. Am J Infect Control 2016;44(Suppl):53-62.

21. Rutala WA, Weber DJ. New developments in reprocessing semicritical items. Am J Infect Control 2013;41(Suppl):60-6.

22. Rutala WA, Gergen MF, Weber DJ. Disinfection of a probe used in ultrasoundguided prostate biopsy. Infect Control Hosp Epidemiol 2007;28:916-9.

23. Rutala WA, Gergen MF, Weber DJ. Disinfection of an infrared coagulation device used to treat hemorrhoids. Am J Infect Control 2012;40:78-9.

24. Food and Drug Administration. FDA-cleared sterilants and high level disinfectants with general claims for processing reusable medical and dental devices. Available from: https://www.fda.gov/medicaldevices/deviceregulationandguidance/reprocessingofreusablemedicaldevices/ucm437347.htm. Accessed January 2019.

25. Rutala WA, Weber DJ. Reprocessing semicritical items: outbreaks and current issues. Am J Infect Control 2019;47(Suppl):A79-89.

26. Rutala WA, Weber DJ. How to assess risk of disease transmission to patients when there is a failure to follow recommended disinfection and sterilization guidelines Infect Control Hosp Epidemiol 2007:28:146-55.

27. Sehulster L, Chinn RY. Centers for Disease Control and Prevention. Healthcare Infection Control Practices Advisory Committee. Guidelines for environmental infection control in health-care facilities. Recommendations of CDC and the Healthcare Infection Control Practices Advisory Committee (HICPAC). MMWR Recomm Rep 2003;52:1-42.

28. Thompson J, Garrett JH Jr. Transducer disinfection for assessment and insertion of peripheral and central catheters. Available from: https://www.avainfo.org/page/ UltrasoundDisinfect. Accessed January 21, 2019.

29. Kanamori H, Rutala WA, Weber DJ. The role of patient care items as a fomite in healthcare-associated outbreaks and infection prevention. Clin Infect Dis 2017;65:1412-9

30. John A, Alhmidi H, Cadnum JL, Jencson AL, Donskey CJ. Contaminated portable equipment is a potential vector for dissemination of pathogens in the intensive care unit. Infect Control Hosp Epidemiol 2017;38:1247-9.
31. Suwantarat N, Supple LA, Cadnum JL, Sankar T, Donskey CJ. Quantitative assessment on interactions between hospitalized patients and portable medical equipment and other fomites. Am J Infect Control 2017;45:1276-8.

32. Deshpande A, Cadnum JL, Fertelli D, Sitzlar B, Thota P, Mana TS, et al. Are hospita floors an underappreciated reservoir for transmission of health care-associated pathogens. Am J Infect Control 2017;45:336-8.

33. Koganti S, Alhmidi H, Tomas ME, Cadnum JL, Jencson A, Donskey CJ. Evaluation of hospital floors as a potential source of pathogen dissemination using a nonpathogenic virus as a surrogate marker. Infect Control Hosp Epidemiol 2016;37:1374-7.

34. Huslage K, Rutala WA, Sickbert-Bennett E, Weber DJ. A quantitative approach to defining "high-touch" surfaces in hospitals. Infect Control Hosp Epidemiol 2010;31:850-3

35. Weber DJ, Rutala WA. Environmental issues and nosocomial infections. In: Wenzel RP, ed. Prevention and control of nosocomial infections, 3rd ed Baltimore (MD): Williams and Wilkins; 1997:491-514.

36. Weber DJ, Rutala WA, Miller MB, Huslage K, Sickbert-Bennett E. Role of hospital surfaces in the transmission of emerging health care-associated pathogens: norovirus, Clostridium difficile, and Acinetobacter species. Am J Infect Control 2010;38 (Suppl):25-33.

37. Best M, Sattar SA, Springthorpe VS, Kennedy ME. Efficacies of selected disinfectants against Mycobacterium tuberculosis. J Clin Microbiol 1990;28:2234-9.

38. Best M, Kennedy ME, Coates F. Efficacy of a variety of disinfectants against Listeric spp. Appl Environ Microbiol 1990;56:377-80.

39. Best M, Springthorpe VS, Sattar SA. Feasibility of a combined carrier test for disinfectants: studies with a mixture of five types of microorganisms. Am J Infect Control 1994;22:152-62.

40. Rutala WA, Barbee SL, Aguiar NC, Sobsey MD, Weber DJ. Antimicrobial activity of home disinfectants and natural products against potential human pathogens. Infect Control Hosp Epidemiol 2000;21:33-8.

41. Rutala WA, Gergen MF, Weber DJ. Efficacy of improved hydrogen peroxide against important healthcare-associated pathogens. Infect Control Hosp Epidemiol 2012;33:1159-61

42. West AM, Teska PJ, Oliver HF. There is no additional bactericidal efficacy of Environmental Protection Agency-registered disinfectant towelettes after surface drying or beyond label contact time. Am J Infect Control 2019;47:27-32.

43. Rutala WA, Weber DJ. Selection of the ideal disinfectant. Infect Control Hosp Epidemiol 2014;35:855-65.

44. Rutala WA, Weber DJ. Surface disinfection: treatment time (wipes/sprays) versus contact time (liquids). Infect Control Hosp Epidemiol 2018;39:329-31.

45. Boyce JM, Pittet D. Healthcare Infection Control Practices Advisory Committee. Society for Healthcare Epidemiology of America. Association for Professionals in Infection Control. Infectious Diseases Society of America. Hand Hygiene Task Force. Guideline for hand hygiene in health-care settings: recommendations of the Healthcare Infection Control Practices Advisory Committee and the HICPAC/SHEA/APIC IDSA Hand Hygiene Task Force. Infect Control Hosp Epidemiol 2002;23(Suppl):3-40.

46. Rutala WA, Weber DJ. Cleaning, disinfection and sterilization. In: Grota P, ed. APIC text of infection control and epidemiology, 4th ed Washington (DC): Association for Professionals in Infection Control and Epidemiology; 2014:1-15.

47. Rutala WA, Weber DJ. Disinfection and sterilization in health care facilities: an overview and current issues. Infect Dis Clin North Am 2016;30:609-37.

48. Rutala WA, Weber DJ. Disinfection and sterilization in health care facilities: what clinicians need to know. Clin Infect Dis 2004;39:702-9.

49. Kohn WG, Collins AS, Cleveland JL, Harte JA, Eklund KJ, Malvitz DM. Centers for Disease Control and Prevention. Guidelines for infection control in dental healthcare settings-2003. MMWR Recomm Rep 2003;52:1-61

50. Rutala WA, Weber DJ. Guideline for disinfection and sterilization of prion-contaminated medical instruments. Infect Control Hosp Epidemiol 2010;31:107-17.

51. Weber DJ, Rutala WA, Sickbert-Bennett EE. Outbreaks associated with contaminated antiseptics and disinfectants. Antimicrob Agents Chemother 2007;51:4217-24.

52. Rutala WA, Cole EC, Thomann CA, Weber DJ. Stability and bactericidal activity of chlorine solutions. Infect Control Hosp Epidemiol 1998:19:323-7.

53. Bruce B, Sheibani-Rad S, Appleyard D, Calfee RP, Reinert SE, Chapin KC, et al. Are dropped osteoarticular bone fragments safely reimplantable in vivo? J Bone Joint Surg Am 2011:93:430-8.

54. Bauer J, Liu RW, Kean TJ, Dennis JE, Petersilige W, Gilmore A. A comparison of five treatment protocols for contaminated bone grafts in reference to sterility and cell viability. J Bone Joint Surg Am 2011;93:439-44. 